\title{
CONTROLLING Metisa plana Walker (Lepidoptera: Psychidae) OUTBREAK USING Bacillus thuringiensis AT AN OIL PALM PLANTATION IN SLIM RIVER, PERAK, MALAYSIA
}

\author{
NOORHAZWANI KAMARUDIN*; SITI RAMLAH AHMAD ALI*; MOHAMED MAZMIRA MOHD MASRI; \\ MOHD NAJIB AHMAD*; CHE AHMAD HAFIZ CHE MANAN* and NORMAN KAMARUDIN*
}

\begin{abstract}
Aerial spraying of Bacillus thuringiensis (Bt)-based biopesticides, Ecobac-1 (EC) was carried out at an oil palm plantation in Slim River, Perak, Malaysia to control the outbreak of bagworm, Metisa plana. Close monitoring of bagworm census, precise timing and follow-up aerial spraying of Ecobac-1 (EC) were important strategies for controlling the multi-stage bagworm outbreak. The first aerial spraying of Ecobac-1 (EC) which was conducted on 11 October 2013 had successfully reduced the first generation larvae population from 187.1 larvae per frond (LPF) eight days prior to treatment to 77.6 LPF at 14 days after treatment (DAT), indicating $56.0 \%$ reduction in bagworm population. The second aerial spraying of Ecobac-1 (EC) undertaken on 19 December 2013, had reduced the second generation larvae population from 358.7 LPF a day prior to treatment to 105.2 LPF at 14 DAT, which resulted in $70.7 \%$ reduction in bagworm population. Whilst the third aerial spraying done on 7 March 2014 had further reduced the population from 51.3 LPF three days prior to treatment to $17.2 \mathrm{LPF}$ at 14 DAT, indicated a $66.4 \%$ reduction. The three consecutive aerial spraying of Ecobac-1 (EC) to control the three generations of M. plana at an oil palm plantation in Slim River, Perak successfully reduced the overall bagworm population by $90.8 \%$. Therefore, it is recommended for the management to conduct a constant vigilance and census for successive control of bagworm population below the economic threshold level.
\end{abstract}

Keywords: Bacillus thuringiensis, biopesticides, Ecobac-1 (EC), aerial spray, Metisa plana.

Date received: 14 January 2016; Sent for revision: 20 January 2016; Received in final form: 19 August 2016; Accepted: 24 January 2017.

\section{INTRODUCTION}

Bagworms are important leaf-eating pests of oil palm in Malaysia. Bagworm infestations and outbreaks have occurred in Malaysia for over five decades (Cheong and Tey, 2012). This remains to be a problem despite the fact that effective control measures are available. Bagworm infestations can cause about 33\%-40\% yield losses (Basri, 1993). In 2013, bagworm

\footnotetext{
Malaysian Palm Oil Board, 6 Persiaran Institusi, Bandar Baru Bangi, 43600 Kajang,

Selangor, Malaysia.

E-mail: ramlah@mpob.gov.my
}

infestation was an important issue that affected the yield of oil palm due to procrastinated control, especially among smallholders (Tey and Cheong, 2013). According to a previous study in 1929, Metisa plana is ranked as the first most economically significant insect pest of oil palm in Malaysia (Basri et al., 1988). A more recent survey conducted by Norman and Basri (2007) indicated that M. plana was most widely distributed in oil palm plantations in Peninsular Malaysia followed by Pteroma pendula. Based on analysis of historical records of bagworm infestation done by Ho et al. (2011), over 63955 ha of oil palm in 69 estates in Peninsular Malaysia showed M. plana and P. pendula to be the primary 
pests (Ho et al., 2011). Bagworm has been declared as a dangerous pest on 15 of November 2013 under the Malaysia Act 167, Plant Quarantine Act 1976. Under this Act, planters who failed to control the bagworm infestation after receiving the notice will be fined not more than RM 10000 or to be jailed for two years.

Agrichemicals consumption in Malaysia was reported to increase from RM328 million in year 2005 to RM 563 million in 2012 (Malaysian Agricultural Digest, 2013). The sale of insecticides in Malaysia recorded a significant 28\% increase since 2008 (Malaysian Agricultural Digest, 2013). Chemical control has become the major control mechanism in managing bagworm outbreaks in most plantations as compared to smallholdings (Hasber, 2010). Study conducted by Salim et al. (2015) showed the fastest acting of chemical insecticide can be seen 30 days after a single application of chemical insecticides where the larval population dropped below the economic threshold level (ETL). However, over reliance on chemical insecticides to control agricultural pests has often led to the development of other more persistent problems such as resistance of pests to treatment, abundance of harmful chemical residues in the environment and the disruption of beneficial insects populations. Biological control is a method of controlling pests in agriculture that relies on natural agents rather than chemicals. Biopesticides are natural biological agents used to control pests, derived from microbes and plants. They are recommended for use in agriculture by farmers because they are target specific and poses little or no hazard to mankind and the environment (Sethi and Gupta, 2013).

Integrated Pest Management (IPM) is the best strategy for controlling bagworm outbreaks in oil palm cultivated areas (Ramlah et al., 2013; 2007a,b; Mohd Mazmira et al., 2010; Najib et al., 2013). One of the main components of IPM is the application of Bacillus thuringiensis (Bt) which is not affecting the non-target organisms including the oil palm pollinating weevil, Elaeidobius kamerunicus (Najib et al., 2012). Bt as an environmental-friendly microbial insecticide is generally not toxic to freshwater fish (Najib et al., 2014), human, domestic animals and vertebrates (Najib et al., 2015). The crystalline protein inclusions produced by $B$. thuringiensis during sporulation are responsible for the insecticidal actions (Nester et al., 2002) and the proteins are highly specific against certain insects orders (Hofte and Whitely, 1989). The Malaysian Palm Oil Board (MPOB) has developed a local Bt-based biopesticides product known as Ecobac-1 (EC).

This study deliberates on the strategy, the importance of regular census and follow-up aerial spraying of Ecobac-1 (EC) for controlling a multistage bagworm outbreaks at an oil palm plantation at Slim River, Perak, Malaysia.

\section{MATERIALS AND METHODS}

\section{Mass Propagation of Bacillus thuringiensis (Bt)}

B. thuringiensis was mass produced using liquid state fermentation and laboratory prepared medium in 5 to 500 litres bioreactors (Satrorius Stedim, Germany) for $48 \mathrm{hr}, 30^{\circ} \mathrm{C}$ at MPOB Microbial Technology and Engineering Centre (MICROTEC) (Najib et al., 2012). Mass production of microbial insecticide based on local isolates known as MPOB Bt1 for controlling bagworm has been patented (Patent No. PI2011000307) (Ramlah et al., 2011). Ecobac-1 (EC) is an emulsified product derived from an indigenous strain of $B$. thuringiensis (MPOB Bt1) (Ramlah and Basri, 1997). The active ingredients of Ecobac-1 (EC) comprised of spores and $\delta$-endotoxins and standardised to $1600 \mathrm{IU} \mathrm{mg}^{-1}$.

\section{Aerial Spray}

Aerial spray was conducted at timely intervals against the susceptible first to fourth larval instars of M. plana at an oil palm plantation in Slim River, Perak in 2013-2014. The aerial spray is scheduled based on the generations of the bagworm. The average life cycle for M. plana from eggs to adult is 103.5 days (Chua et al., 2011). The first (G1), second (G2) and third (G3) generations of the bagworm were aerial sprayed on 11 October 2013, 19 December 2013 and 7 March 2014, respectively. The bagworm infested area was GPS-mapped and aerial sprayed with 40 litres Ecobac-1 (EC) diluted in an aircraft tank using 1000 litres of water. Spraying was conducted by an aerial spraying services company using an AgCat aircraft.

\section{Bagworms Census}

Bagworm pre-census was conducted before aerial spray operation to count and record the initial bagworm population. Post-census counts of the M. plana populations were conducted 7, 14, and 28 days after treatment (DAT). One percent of the infested area was censused by taking one palm at every $10^{\text {th }}$ palms at every $10^{\text {th }}$ row. One frond from the middle of the canopy showing fresh damage symptoms was cut down for counting the number of larvae and pupae on both sides of the frond. The control procedures must be conducted once the eggs within the female pupal bags hatch into early larval stages (Norman et al., 2004; Ramlah et al., $2007 a, b)$. When the larval population is at the early instar stages (first to fourth larval instars) and the number is above the threshold level (5-10 larvae per frond) (Wood, 2002), control measures should start immediately. If more than $70 \%$ of the population are at the late instars (fifth to seventh larval instars) or pupal stages, the aerial spray using Bt must be 
postponed (Basri, 1993; Ramlah et al., 2007a,b). The aerial spray would be carried out on the next generation of $M$. plana once the early larval stages emerge.

\section{Data Analysis}

Data on the field survival of bagworms treated with the Bt product was analysed using twoway ANOVA (Sigma-plot version 12.5 and SAS version 9.4). The means were separated using Least Significant Difference (LSD). The time course population dynamic of the different stages of bagworms was closely monitored for precision in follow-up sprays.

\section{RESULTS AND DISCUSSION}

The application of Ecobac-1 (EC) via aerial spraying for controlling multi-stage bagworm outbreaks in Southern Perak focused on a hotspot area at an oil palm plantation in Slim River, Perak with three round of Ecobac-1 (EC) spraying from October 2013 to March 2014, covering an infested area of 292 ha (Figure 1) from total area of 2032 ha.

The first round of Ecobac-1 (EC) aerial spraying began on 11 October 2013. Eight days before the treatment, the pooled average census of leaf eating larvae was 187.1 larvae per frond (LPF) (Figure 2 and Table 1). Spraying was sometimes delayed due to aircraft technical problems and unsuitable weather (rain) or high wind speed (more than 10 knots). After the first round spraying of Ecobac-1 (EC), the pooled average larval population decreased significantly from 187.1 LPF to 77.6 LPF at 14 DAT (Figure 2 and Table 1) with $58.5 \%$ reduction of larval population.

The second round of aerial spraying commenced on 19 December 2013. The average larvae census prior to treatment was slightly higher compared to the first generation which was 358.7 LPF (Table 2). The initial bagworm population was high, 358.7 LPF, due to the high number of pupae at the end of previous generation of bagworm. This high number of bagworm is not due to drought, since the rainfall was quite high $(416 \mathrm{~mm})$ at the beginning of the first and second generations. The second round spraying of Ecobac-1 (EC) resulted in a significant decrease in the larval population from 358.7 LPF to 105.2 LPF at 14 DAT (Figure 2 and Table 2) with $70.7 \%$ reduction of larval population.

The third round of Ecobac-1 (EC) aerial spraying was conducted on 7 March 2014. Three days prior to treatment, the pooled average census indicated M. plana infestation significantly reduced from 51.3
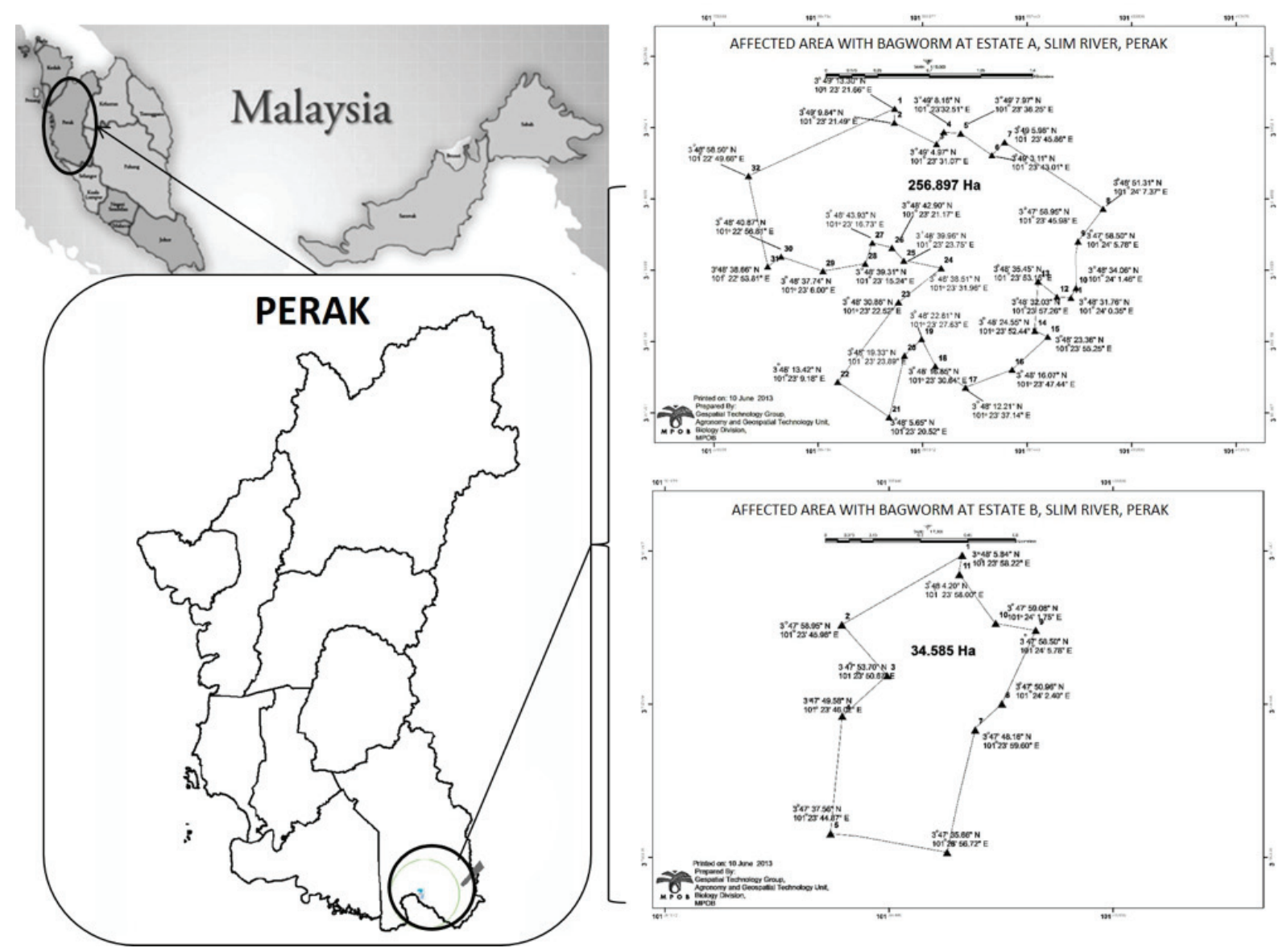

Figure 1. Bagworm infestation area at an oil palm plantation A and B in Slim River, Perak. 
TABLE 1. EFFECT OF ECOBAC-1 (EC) AGAINST BAGWORM SURVIVAL BEFORE AND AFTER THE FIRST AERIAL SPRAY

\begin{tabular}{|c|c|c|c|c|c|c|c|c|c|c|c|c|}
\hline \multirow{2}{*}{$\begin{array}{l}\text { Bagworm } \\
\text { stage }\end{array}$} & \multicolumn{3}{|c|}{ Pre-census (3/10/2013) } & \multicolumn{3}{|c|}{7 DAT (18/10/2013) } & \multicolumn{3}{|c|}{14 DAT (25/10/2013) } & \multicolumn{3}{|c|}{28 DAT (8/11/2013) } \\
\hline & Mean \pm S.E & Range & Median & Mean \pm S.E & Range & Median & Mean \pm S.E & Range & Median & Mean \pm S.E & Range & Median \\
\hline L2 & 0 & 0 & 0 & 0 & 0 & 0 & 0 & 0 & 0 & 0 & 0 & 0 \\
\hline L3 & $185.6 \pm 9.3$ & $0-541$ & 158 & 0 & 0 & 0 & 0 & 0 & 0 & 0 & 0 & 0 \\
\hline L4 & $1.4 \pm 0.12$ & $0-7$ & 0 & $2.4 \pm 0.2$ & $0-9$ & 2 & 0 & 0 & 0 & 0 & 0 & 0 \\
\hline L5 & 0 & 0 & 0 & $136.0 \pm 2.2$ & $0-99$ & 133 & $15.3 \pm 1.3$ & $0-44$ & 14 & 0 & 0 & 0 \\
\hline L6 & 0 & 0 & 0 & $28.4 \pm 0.7$ & $0-31$ & 27 & $41.4 \pm 3.3$ & $0-168$ & 35 & 0 & 0 & 0 \\
\hline L7 & 0 & 0 & 0 & 0 & 0 & 0 & $20.8 \pm 1.6$ & $0-60$ & 13.5 & $18.9 \pm 1.8$ & $0-76$ & 15 \\
\hline Pupae & 0 & 0 & 0 & 0 & 0 & 0 & $4.7 \pm 0.8$ & $0-40$ & 0 & $29.9 \pm 2.7$ & $0-120$ & 20 \\
\hline $\begin{array}{l}\text { Overall mean } \\
\text { larvae } \\
\text { (per frond) }\end{array}$ & $187.1 \pm 9.3^{\mathrm{a}}$ & $0-541$ & 159 & $166.9 \pm 2.3^{a}$ & $0-109$ & 163.5 & $77.6 \pm 5.4^{\mathrm{b}}$ & $0-201$ & 64 & $18.9 \pm 1.8^{c}$ & $0-76$ & 15 \\
\hline $\begin{array}{l}\text { Overall mean } \\
\text { bagworm } \\
\text { (per frond) }\end{array}$ & $187.1 \pm 9.3^{\mathrm{a}}$ & $0-541$ & 159 & $166.9 \pm 2.3^{a}$ & $0-109$ & 163.5 & $82.3 \pm 5.7^{b}$ & $0-201$ & 69.5 & $48.9 \pm 3.5^{c}$ & $0-140$ & 46 \\
\hline \multicolumn{13}{|l|}{$\%$ Larvae } \\
\hline \multicolumn{2}{|l|}{$\%$ Bagworm } & & & \multicolumn{3}{|c|}{$10.8^{c}$} & \multicolumn{3}{|c|}{$58.5^{\mathrm{b}}$} & \multicolumn{2}{|c|}{$89.9^{a}$} & \\
\hline
\end{tabular}

Note: Aerial spray was conducted on 11 October 2013.

Pre-census of bagworm was conducted on 3 October 2013, eight days prior to treatment. It was delayed in spraying due to some technical problem and unsuitable weather.

'L' indicates bagworm larval instars.

Mean with the same letters are not significantly different based on Least Significant Difference (LSD) comparison test ( P $>0.05$ ).

$\mathrm{DAT}=$ days after treatment (aerial spray of Bt).

Data in percentage $(\%)$ has been arcsine transformed before analysis.

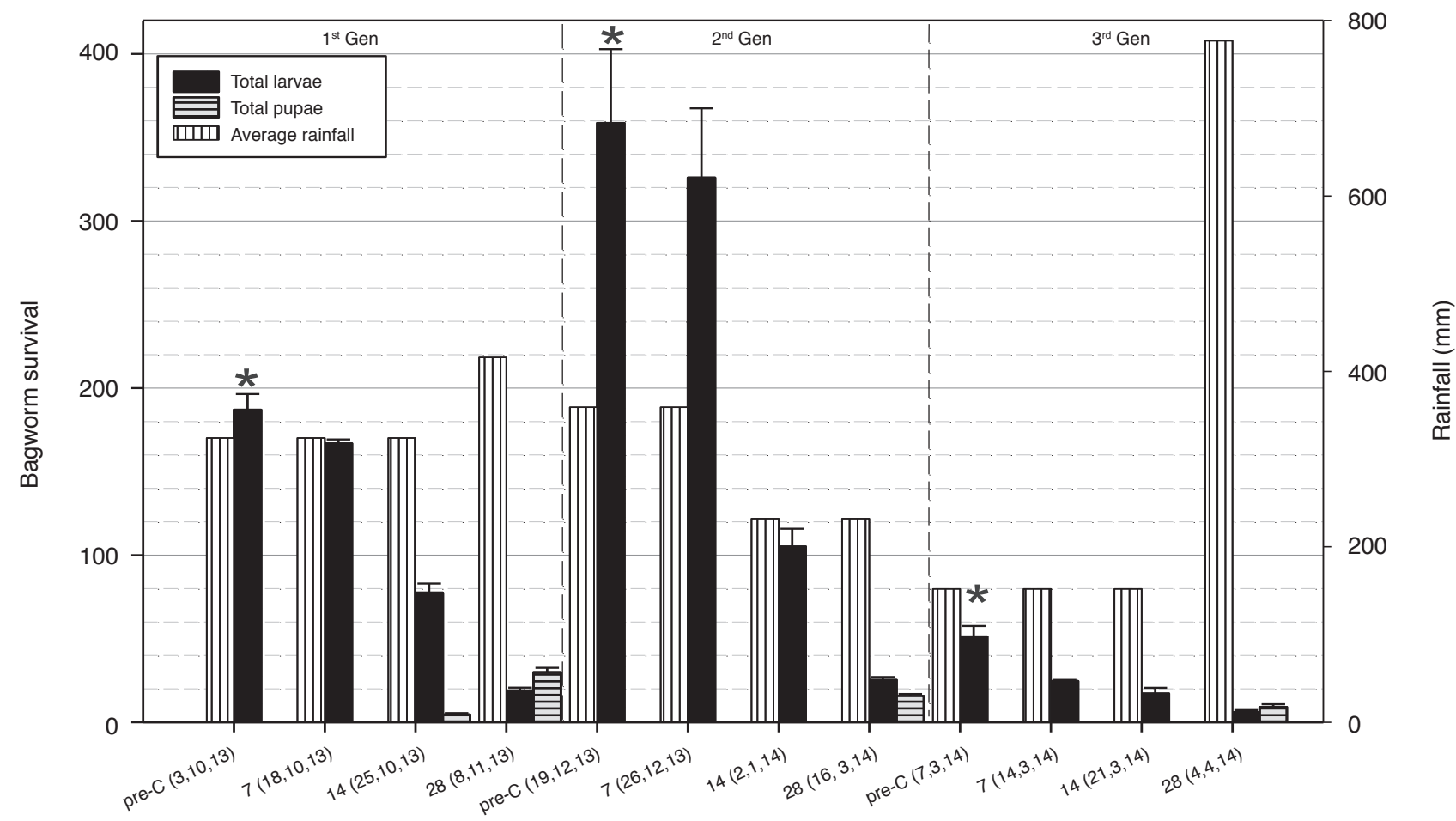

Day after treatment (date of assesment)

Note: Number of aerial spray was based on bagworm's population generation; spraying was conducted on 11 October 2013, 19 December 2013 and 7 March 2014 as indicated by star*. Total sprayed area was 292 ha.

Figure 2. Average larvae population of Metisa plana subjected to aerial spray of three different generations (G1 2013, G2 2013 and G3 2014) at an oil palm plantation in Slim River, Perak. 
TABLE 2. EFFECT OF ECOBAC-1 (EC) AGAINST BAGWORM SURVIVAL BEFORE AND AFTER THE SECOND AERIAL SPRAY

\begin{tabular}{|c|c|c|c|c|c|c|c|c|c|c|c|c|}
\hline \multirow{2}{*}{$\begin{array}{l}\text { Bagworm } \\
\text { stage }\end{array}$} & \multicolumn{3}{|c|}{ Pre-census (19/12/2013) } & \multicolumn{3}{|c|}{7 DAT (26/12/2013) } & \multicolumn{3}{|c|}{14 DAT (2/1/2014) } & \multicolumn{3}{|c|}{28 DAT (16/1/2014) } \\
\hline & Mean \pm S.E & Range & Median & Mean \pm S.E & Range & Median & Mean \pm S.E & Range & Median & Mean \pm S.E & Range & Median \\
\hline L1 & 0 & 0 & 0 & 0 & 0 & 0 & 0 & 0 & 0 & 0 & 0 & 0 \\
\hline L2 & 0 & 0 & 0 & 0 & 0 & 0 & 0 & 0 & 0 & 0 & 0 & 0 \\
\hline L3 & $280.2 \pm 35.8$ & $0-1308$ & 56 & 0 & 0 & 0 & 0 & 0 & 0 & 0 & 0 & 0 \\
\hline L4 & $78.5 \pm 11.9$ & $0-552$ & 18.5 & $256.4 \pm 33.7$ & $0-1238$ & 54.5 & 0 & 0 & 0 & 0 & 0 & 0 \\
\hline L5 & 0 & 0 & 0 & $69.6 \pm 8.9$ & $0-316$ & 21.5 & $36.9 \pm 3.6$ & $0-187$ & 32.5 & 0 & 0 & 0 \\
\hline L6 & 0 & 0 & 0 & 0 & 0 & 0 & $68.3 \pm 7.4$ & $0-396$ & 48.5 & $5.9 \pm 0.7$ & $0-24$ & 3 \\
\hline L7 & 0 & 0 & 0 & 0 & 0 & 0 & 0 & 0 & 0 & $19.4 \pm 1.5$ & $0-60$ & 13 \\
\hline Pupae & 0 & 0 & 0 & 0 & 0 & 0 & 0 & 0 & 0 & $15.8 \pm 1.1$ & $0-41$ & 17 \\
\hline $\begin{array}{l}\text { Overall mean } \\
\text { larvae } \\
\text { (per frond) }\end{array}$ & $358.7 \pm 44.2^{\mathrm{a}}$ & 0-1431 & 103 & $325.9 \pm 41.5^{\mathrm{a}}$ & 0-1391 & 76 & $105.2 \pm 10.6^{\mathrm{b}}$ & $0-583$ & 75.5 & $25.3 \pm 1.7^{c}$ & $0-81$ & 24 \\
\hline $\begin{array}{l}\text { Overall mean } \\
\text { bagworm } \\
\text { (per frond) }\end{array}$ & $358.7 \pm 44.2^{\mathrm{a}}$ & 0-1431 & 103 & $325.9 \pm 41.5^{\mathrm{a}}$ & 0-1391 & 76 & $105.2 \pm 10.6^{b}$ & $0-583$ & 75.5 & $41.1 \pm 2.1^{b}$ & $0-99$ & 37.5 \\
\hline $\begin{array}{l}\% \text { Larvae } \\
\text { reduction }\end{array}$ & & - & & & $9.1^{c}$ & & & $70.7^{\mathrm{b}}$ & & & $92.9^{a}$ & \\
\hline $\begin{array}{l}\% \text { Bagworm } \\
\text { reduction }\end{array}$ & & - & & & $9.1^{c}$ & & & $70.7^{\mathrm{b}}$ & & & $88.5^{\mathrm{a}}$ & \\
\hline
\end{tabular}

Note: Aerial spray was conducted on 19 December 2013.

'L' indicates bagworm larval instars.

Mean with the same letters are not significantly different based on Least Significant Difference (LSD) comparison test ( P $>0.05)$.

DAT $=$ days after treatment (aerial spray of Bt).

Data in percentage $(\%)$ has been arcsine transformed before analysis.

LPF to 17.2 LPF at 14 DAT (Figure 2 and Table 3) with $66.4 \%$ reduction of larval population. At $28 \mathrm{DAT}$, the average larval population had reduced to 6.1 LPF indicating that the M. plana population was already below the threshold level of 10 LPF.

There was a recurring infestation during the second round of aerial spray. Based on Table 1, there were pupae present at 14 DAT and 28 DAT after the first generation spraying of Ecobac-1 (EC), the pupae per frond (PPF) were 4.7 PPF and 29.9 PPF, respectively. Hence, the occurrence of eggs hatching from the previous generation caused a higher larval population (358.7 LPF with an average of 280.2 LPF and 78.5 LPF of the third and fourth larval instars, respectively) before the treatment.

It was noted that at 28 DAT of the second aerial spraying of Ecobac-1 (EC), the pupal number of the second generation bagworm had significantly decreased to 15.8 PPF with a range of 0-41 PPF (Table 2). Three days prior to the treatment of the third generation, the total larval population was 51.3 LPF. It was lower compared to the previous bagworm population with an average of $14.8 \mathrm{LPF}, 29.5 \mathrm{LPF}$ and 7.0 LPF for the second, third and fourth larval instars, respectively. This showed that the bagworm population had reduced significantly for the second round of aerial spray. At $28 \mathrm{DAT}$, the pooled average pupal population was recorded at 9.2 PPF (Table 3).

Natural enemies such as predators, parasitoids and pathogens were found to be associated with mortality on bagworms and naturally controlling the bagworm population in oil palm plantation (Cheong et al., 2010). From a study, conducted by the Palm Oil Research Institute of Malaysia (PORIM) in 1989 on the population of M. plana at PORIM Kluang, Johor, Malaysia mortality for each instar caused by natural enemies from the first to the seventh instars were $\mathrm{I}=4.9 \%$, II $=16.7 \%$, III $=65.6 \%$, IV $=87.5 \%, \mathrm{~V}=79.6 \%$, $\mathrm{VI}=67.4 \%$ and $\mathrm{VII}=51.2 \%$, respectively (Basri, 1993). Based on study by Cheong et al. (2010), the natural enemies such as predators, parsitoids and pathogens were responsible for causing mortality to the bagworms about $37 \%, 35.9 \%$ and $27.2 \%$ of bagworms mortality, respectively. Based on both studies done by Basri (1993) and Cheong et al. (2010), the reduction of bagworm population was not only caused by the application of Bt product, but these biotic and abiotic factors also played an important role in reducing the bagworm population and regulating the larval community.

The results showed that the bagworm populations fluctuated throughout the year (Figure 2). Figure 3 shows the severe bagworm infestation before aerial spray with Bt (brownish) and the oil palm recovered (green) almost completely two years after treatment. According to the rainfall data at the oil palm plantation (Figure 2), the rainfall volume was $359 \mathrm{~mm}$ in December 2013 during the second generation of bagworm. During the third generation of bagworm in March 2014, there was lesser 

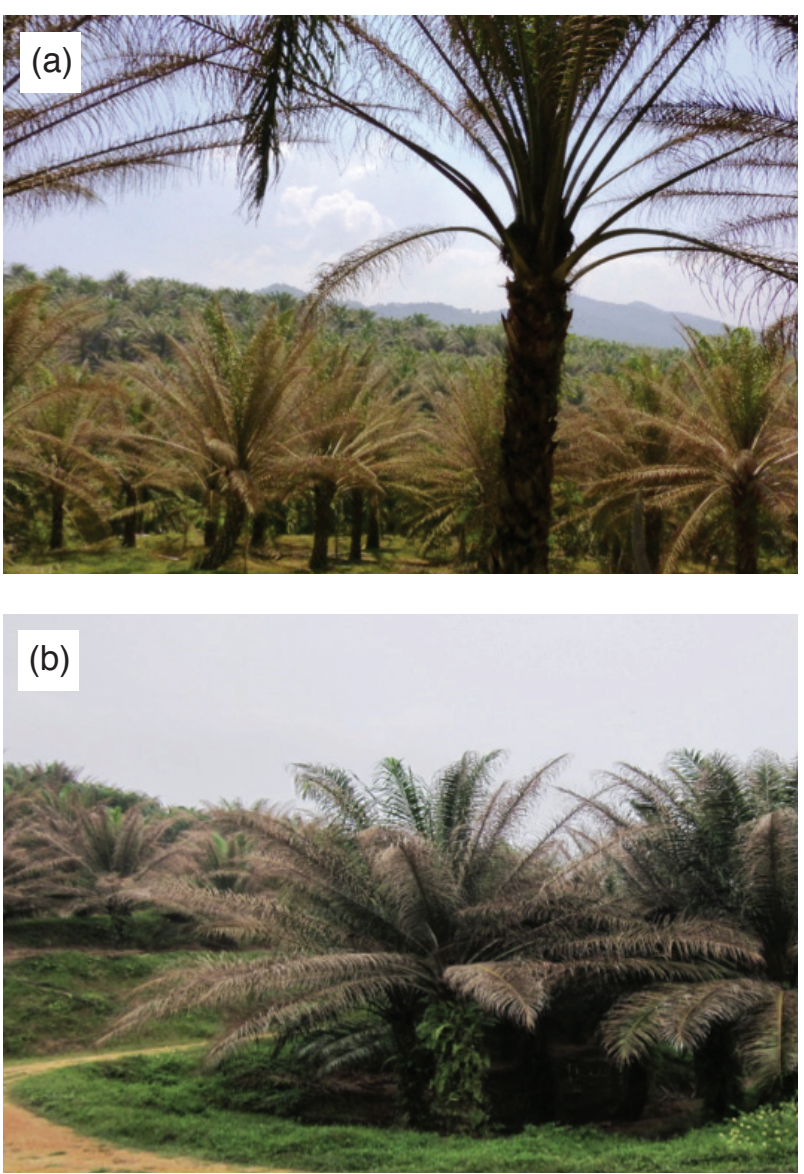

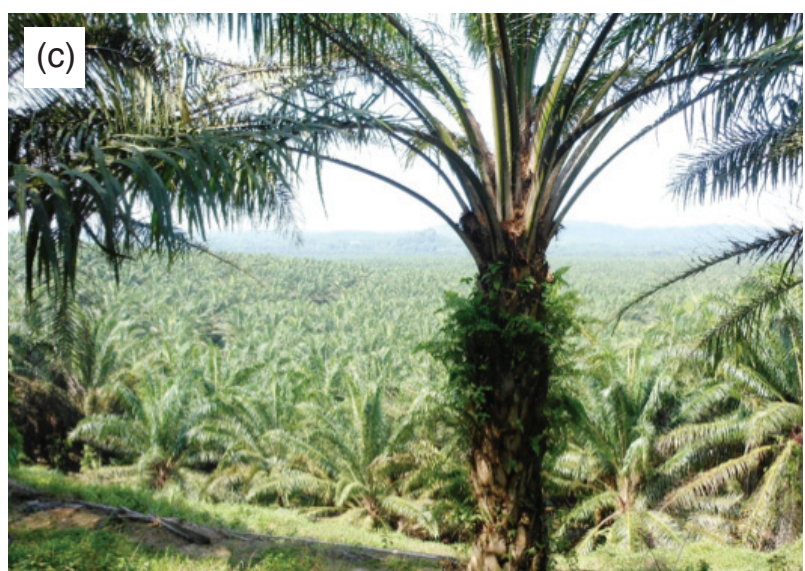

(d)

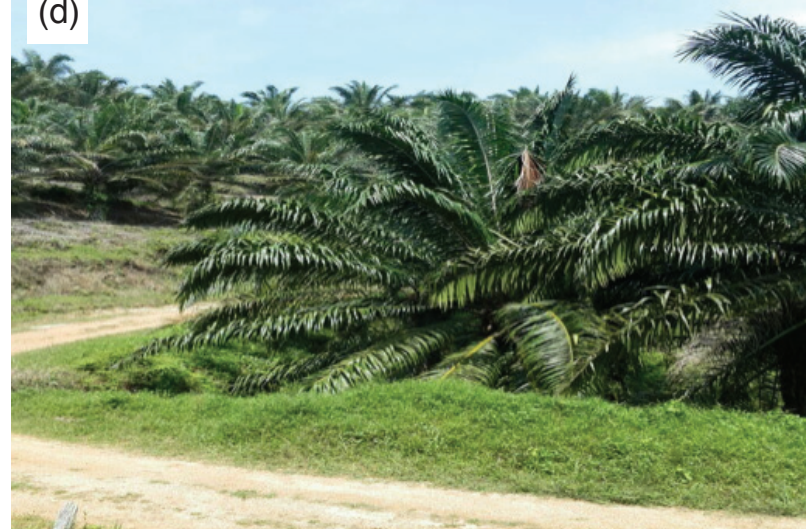

Figure 3. Leaf damage caused by Metisa plana before treatment with Bacillus thuringiensis, Bt in 2013 (a and c) and two years after treatment in 2015 ( $b$ and $d)$ at an oil palm plantation A and B in Slim River, Perak.

rainfall $(152 \mathrm{~mm})$. However, the pooled average larvae for the second generation of bagworm was much higher, at 358.7 LPF compared to the third generation of bagworm which was 51.3 LPF, despite the lower rainfall. Thus, it seemed that the bagworm population was not affected by rainfall. Similar studies have shown that the bagworm numbers were not correlated with weather parameters (Chung and Sim, 1991; Cheong et al., 2010; Ho et al., 2011; Ahya et al., 2012). However, heavier rainfall should make the bagworm inactive and feeding less. Figure 2 shows that, heavy rainfall during the first and third generation population had resulted in total bagworm reduction of $56.0 \%$ (Table 1) and $66.4 \%$ (Table 3), respectively. As for the second aerial spray, the high total reduction in bagworm $(70.7 \%)$ (Table 2) might be due to the susceptibility of the third larval instar to Bt plus drier conditions which might be condusive for the bagworm to feed more.

Other factors that might be responsible for the spread in bagworm populations are strong wind, vehicles, animal and human (Cheong and Tey, 2012). These could be the dispersal factors of the bagworm in oil palm plantation, which contributed to the increased bagworm population in this oil palm plantation.
Alternate host plants in the environment could also contribute to the continuing bagworm infestation, as the alternate host plants provide a persistent breeding site for the pest (Cheong and Tey, 2013). As a polyphagous insect, M. plana lives in a wide range of host plants (Ahmad and Ho, 1980). The bagworm may continue to survive on other host plants within the oil palm vicinity when the palms were being treated with Ecobac-1 (EC).

\section{CONCLUSION}

Proper strategy, consistent census and followup aerial spraying with Ecobac-1 (EC) have successfully controlled M. plana outbreaks at an oil palm plantation in Slim River, Perak. It is important for the estate management concerned, to continue monitoring the presence of bagworm and implement the IPM system to keep the M. plana population below the threshold level.

\section{ACKNOWLEDGEMENT}

The authors would like to thank the DirectorGeneral of MPOB for permission to publish this article. The authors wish to thank the manager of 
TABLE 3. EFFECT OF ECOBAC-1 (EC) AGAINST BAGWORM SURVIVAL BEFORE AND AFTER THE THIRD AERIAL SPRAY

\begin{tabular}{|c|c|c|c|c|c|c|c|c|c|c|c|c|}
\hline \multirow{2}{*}{$\begin{array}{l}\text { Bagworm } \\
\text { stage }\end{array}$} & \multicolumn{3}{|c|}{ Pre-census (4/3/2014) } & \multicolumn{3}{|c|}{7 DAT (14/3/2014) } & \multicolumn{3}{|c|}{14 DAT (21/3/2014) } & \multicolumn{3}{|c|}{28 DAT (4/4/2014) } \\
\hline & Mean \pm S.E & Range & Median & Mean \pm S.E & Range & Median & Mean \pm S.E & Range & Median & Mean \pm S.E & Range & Median \\
\hline L2 & $14.8 \pm 1.7$ & $0-61$ & 8 & 0 & 0 & 0 & 0 & 0 & 0 & 0 & 0 & 0 \\
\hline L3 & $29.5 \pm 3.8$ & $0-124$ & 14 & $3.5 \pm 0.3$ & $0-14$ & 3 & 0 & 0 & 0 & 0 & 0 & 0 \\
\hline L4 & $7 \pm 1.0$ & $0-34$ & 3 & $3.9 \pm 0.3$ & $0-11$ & 3 & 0 & 0 & 0 & 0 & 0 & 0 \\
\hline L5 & 0 & 0 & 0 & $17.2 \pm 0.5$ & $0-29$ & 17 & $7.2 \pm 1.6$ & $0-71$ & 0 & 0 & 0 & 0 \\
\hline L6 & 0 & 0 & 0 & 0 & 0 & 0 & $10.1 \pm 1.9$ & $0-81$ & 0 & 0 & 0 & 0 \\
\hline L7 & 0 & 0 & 0 & 0 & 0 & 0 & 0 & 0 & 0 & $6.1 \pm 1.2$ & $0-55$ & 0 \\
\hline Pupae & 0 & 0 & 0 & 0 & 0 & 0 & 0 & 0 & 0 & $9.2 \pm 1.6$ & $0-61$ & 0 \\
\hline $\begin{array}{l}\text { Overall mean } \\
\text { larvae } \\
\text { (per frond) }\end{array}$ & $51.3 \pm 6.3^{\mathrm{a}}$ & $0-205$ & 33 & $24.6 \pm 0.7^{b}$ & $0-43$ & 25 & $17.2 \pm 3.4^{\mathrm{b}}$ & $0-138$ & 0 & $6.1 \pm 1.2^{c}$ & $0-55$ & 0 \\
\hline $\begin{array}{l}\text { Overall mean } \\
\text { bagworm } \\
\text { (per frond) }\end{array}$ & $51.3 \pm 6.3^{\mathrm{a}}$ & $0-205$ & 33 & $24.6 \pm 0.7^{b}$ & $0-43$ & 25 & $17.2 \pm 3.4^{b}$ & $0-138$ & 0 & $15.2 \pm 2.7^{b}$ & $0-105$ & 0 \\
\hline $\begin{array}{l}\% \text { Larvae } \\
\text { reduction }\end{array}$ & & - & & & $51.9^{c}$ & & & $66.4^{\mathrm{b}}$ & & & $88.2^{\mathrm{a}}$ & \\
\hline $\begin{array}{l}\% \text { Bagworm } \\
\text { reduction }\end{array}$ & & - & & & $51.9^{b}$ & & & $66.4^{\mathrm{a}}$ & & & $70.3^{a}$ & \\
\hline
\end{tabular}

Note: Aerial spray was conducted on 7 March 2014.

Pre-census of bagworm was conducted on 4 March 2014, eight days prior to treatment. It was delayed in spraying due to some technical problem and unsuitable weather.

'L' indicates bagworm larval instars.

Mean with the same letters are not significantly different based on Least Significant Difference (LSD) comparison test ( P $>0.05)$.

DAT $=$ days after treatment (aerial spray of $\mathrm{Bt}$ ).

Data in percentage $(\%)$ has been arcsine transformed before analysis.

plantation in Slim River, Perak for his cooperation in conducting the study.

\section{REFERENCES}

AHMAD, Y and HO, T H (1980). List of economic pests, host plants, parasites and predators in West Malaysia (1920-1978). Bulletin, 153. Ministry Agriculture, Kuala Lumpur, Malaysia.

AHYA MAHADI, N; MUHAMAD, R and AZURA ADAM, N (2012). Relationship between bagworm Pteroma pendula Joannis (Lepidoptera: Psychidae) populations, parasitoids, and weather parameters in oil palm plantation. J. Agricultural Science. 4(12): 13-17. http:/ / dx.doi.org/10.5539/jas.v4n12p13

BASRI, $\mathrm{M}$ W; ABDUL, $\mathrm{H} \mathrm{H}$ and ZULFIKRI, $\mathrm{M}$ (1988). Bagworm (Lepidoptera: Psychidae) of Oil Palms in Malaysia. PORIM, Bangi.

BASRI, M W (1993). Life History, Ecology and Economic Impact of the Bagworm, Metisa plana Walker (Lepidoptera: Phychidae), on the Oil Palm, Elaeis guineensis Jacquin (Palmae). Ph.D thesis, University of Guelp, Ontario, Canada.
CHEONG, Y L; SAJAP, A S; HAFIDZI, M N; OMAR, D and ABOOD, F (2010). Outbreaks of bagworms and their natural enemies in an oil palm, Elaeis guineensis, plantation at Hutan Melintang, Perak, Malaysia. J. Entomology. 7: 141-151. http://dx.doi. org / 10.3923 / je.2010.141.151

CHEONG, Y L and TEY, C C (2012). Understanding pest biology and behaviour for effective control of oil palm bagworms. The Planter, 88(1039): 699-715.

CHEONG, Y L and TEY, C C (2013). Environmental factors which influence bagworm outbreak. Proc. of the $5^{\text {th }}$ MPOB-IOPRI International Seminar: Sustainable Management of Pests and Diseases in Oil Palm - The Way Forward. p. 1-20.

CHUA, C H; OOI K E; RAHMAN, A R and ADZEMI, M A (2011). Microstructure and life cycle of Metisa plana Walker (Lepidoptera: Psychidae). J. Sustainability Science and Management, 6(1): 51-59.

CHUNG, G F and SIM, S C (1991). Bagworm census and control. Proc. of the PORIM International Palm Oil Conference - Agriculture. p. 433-442.

HASBER, S (2010). Evaluation of Several Chemical Control Approaches against Bagworm, Metisa plana 
Walker (Lepidoptera: Psychidae) in Felda Oil Palm Plantations. M.Sc. thesis, Universiti Sains Malaysia, Pulau Pinang, Malaysia.

HO, C T; YUSOF, I and KHOO, K C (2011). Infestation by the bagworms Metisa plana and Pteroma pendula for the period 1986-2000 in major oil palm estates managed by Golden Hope Plantation Berhad in Peninsular Malaysia. J. Oil Palm Res. Vol. 23(2): 10401050.

HOFTE, H and WHITELY, H R (1989). Insecticidal crystal proteins of Bacillus thuringiensis. Microbial Reviews, 53: 242-255.

MALAYSIAN AGRICULTURAL DIGEST (2013). Chapter 16: Agricultural chemicals. Malaysian Agricultural Digest. p. 155-163.

MOHD MAZMIRA, M M; RAMLAH, A A S; NAJIB, M A; NORMAN, K; KUSHAIRI, A D and BASRI, M W (2010). Integrated Pest Management (IPM) of bagworms in Southern Perak via aerial spraying of Bacillus thuringiensis (Bt). Oil Palm Bulletin No. 63: 2433.

NAJIB, M A; RAMLAH, A A S; MOHD MAZMIRA, M M and ZAINI, M A (2012). Effect of Bt products, Lepcon-1, Bafog-1 (S) and Ecobac-1 (EC), against the oil palm pollinating weevil, Elaeidobius kamerunicus, and beneficial insects associated with Cassia cobanensis. J. Oil Palm Res. Vol. 24: 1442-1447.

NAJIB, M A; RAMLAH, A A S; MOHD MAZMIRA, M M and BASRI, M W (2013). Efficacy of Bafog-1 (s), formulated local Bacillus thuringiensis for controlling bagworm, Pteroma pendula (Lepidoptera: Psychidae). J. Oil Palm Res. Vol. 25(2): 228-234.

NAJIB, M A; RAMLAH, A A S; MOHD MAZMIRA, M M and NOORAZAH, Z (2014). Lepcon-1, Bafog-1 (S) and Ecobac-1 (EC), Bacillus thuringiensis basedproducts are not toxic against the freshwater fish, Tilapia nilotica. J. Oil Palm Res. Vol. 26(4): 317-320.

NAJIB, M A; RAMLAH, A A S; MOHD MAZMIRA, M M and ZAINI, M A (2015). Effect of Bacillus thuringiensis based-products on rats. J. Oil Palm Res. Vol. 27(1): 30-38.

NESTER, E W; THOMASHOW, L S; METZ, M and GORDOM, M (2002). 100 Years of Bacillus thuringiensis: A Critical Scientific Assessment. Ithaca, New York. p. 22.

NORMAN, K; BASRI, M W; RAMLE, $\mathrm{M}$ and RAMLAH, A A S (2004). Bagworms, rhinocerous beetle and nettle caterpillars - biology, life cycle and control on oil palms in Malaysia. Proc. of the Industrial
Conference on Pests and Diseases of Importance to the Oil Palm Industry. p. 96-116.

NORMAN, K and BASRI, M W (2007). Status of common insect pest in relation to technology adoption. The Planter, 83: 371-385.

NORMAN, K; BASRI, MW and ZULKIFLI, M (2004). Kumbang pendebungaan, perosak sawit dan kawalannya. Perusahaan Sawit di Malaysia - Satu Panduan (Ghani, E A; Zakaria, Z Z and Basri, M W eds.). MPOB, Bangi. p. 144-155.

RAMLAH, A A S; NAJIB, M A; MOHD MAZMIRA, M M M; TAJUDDIN, $\mathrm{N}$ A; KENI, $M$ F and NORMAN, K (2013). Microbial control for pests and diseases and its challenges. Proc. of the PIPOC 2013 International Palm Oil Congres - Agriculture, Biotechnology \& Sustainability Conference. p. 67.

RAMLAH, A A S; NAJIB, M A and MAZMIRA, M M (2011). Method of producing microbial insecticide. Malaysian patent application PI2011000307.

RAMLAH, AAS; NORMAN, K; BASRI, M W; NAJIB, M A; MOHD MAZMIRA, $M$ M and KUSHAIRI, A D (2007a). Manual Pengurusan Bersepadu Ulat Bungkus di Ladang Sawit. MPOB, Bangi. p. 15.

RAMLAH, AAS; NORMAN, K; BASRI, MW;NAJIB, M A; MOHD MAZMIRA, M M and KUSHAIRI, A D (2007b). Sistem Pengurusan Perosak Bersepadu bagi Kawalan Ulat Bungkus di Ladang Sawit. MPOB, Bangi. p. 28.

RAMLAH, A A S and BASRI, M W (1997). A local Bacillus thuringiensis SRBT1 with potential for controlling Metisa plana (Wlk). Elaeis, 9(1): 34-45.

SALIM, H; RAWI, C S M; AHMAD, A H and ALSHAMI, S A (2015). Efficacy of insecticide and bioinsecticide ground sprays to control Metisa plana Walker (Lepidoptera: Psychidae) in oil palm plantations, Malaysia. Tropical Life Sciences Research, 26(2): 73-83.

SETHI, S and GUPTA, S (2013). Impact of pesticides and biopesticides on soil microbial biomass carbon. J. Environmental Research and Technology, 3(2): 326330.

TEY, C C and CHEONG, Y L (2013). Challenges in Integrated Pest Management (IPM). Proc. of $10^{\text {th }}$ NATSEM 2013 - Confronting Management Challenges in the Oil Palm Industry. Incorporated Society of Planters, Kuala Lumpur. p. 117-127.

WOOD, B J (2002). Pest control in Malaysia's perennial crops: a half century perspective tracking the pathway to integrated pest management. Integrated Pest Management Reviews, 7: 173-190. 